\title{
Communication
}

\section{Tetramethyl 1,1'-(2-[\{4,5-bis(Methoxycarbonyl)-1H-1,2,3-triazol- 1-yl\}methyl]-2-[(4-methylphenyl)sulfonamido]propane-1,3- diyl)bis(1H-1,2,3-triazole-4,5-dicarboxylate)}

\author{
Serigne Abdou Khadir Fall ${ }^{1}$, Sara Hajib ${ }^{1}$, Oumaima Karai ${ }^{1}$, Younas Aouine ${ }^{1,2}{ }^{\mathbb{D}}$, Salaheddine Boukhssas ${ }^{1}$, \\ Hassane Faraj ${ }^{1}$ and Anouar Alami ${ }^{1, * \mathbb{D}}$ \\ 1 Engineering Laboratory of Organometallic, Molecular Materials and Environment (LIMOME), Faculty of \\ Sciences Dhar El Mahraz, Sidi Mohammed Ben Abdellah University, 30000 Fez, Morocco; \\ Serigneabdoukhadir.fall@usmba.ac.ma (S.A.K.F.); sara.hajib@usmba.ac.ma (S.H.); \\ oumaima.karai@usmba.ac.ma (O.K.); y.aouine@uiz.ac.ma (Y.A.); salaheddine.boukhssas@usmba.ac.ma (S.B.); \\ hassane.faraj@usmba.ac.ma (H.F.) \\ 2 Team of Organic Chemistry and Valorization of Natural Substances (COVSN), Faculty of Sciences, \\ Ibn Zohr University, 80060 Agadir, Morocco \\ * Correspondence: anouar.alami@usmba.ac.ma; Tel.: +212-661-796-480
}

check for updates

Citation: Fall, S.A.K.; Hajib, S.; Karai, O.; Aouine, Y.; Boukhssas, S.; Faraj, H.; Alami, A. Tetramethyl 1,1'-(2-[\{4,5-bis(Methoxycarbonyl)-1H1,2,3-triazol-1-yl\}methyl]-2-[(4methylphenyl)sulfonamido]propane1,3-diyl)bis(1H-1,2,3-triazole-4,5dicarboxylate). Molbank 2021, 2021, M1186. https://doi.org/ 10.3390/M1186

Academic Editor: Fawaz Aldabbagh Received: 13 January 2021

Accepted: 27 January 2021

Published: 31 January 2021

Publisher's Note: MDPI stays neutral with regard to jurisdictional claims in published maps and institutional affiliations.

Copyright: (c) 2021 by the authors. Licensee MDPI, Basel, Switzerland. This article is an open access article distributed under the terms and conditions of the Creative Commons Attribution (CC BY) license (https:/ / creativecommons.org/licenses/by/ $4.0 /)$.

\begin{abstract}
A new compound tetramethyl 1,1'-(2-[\{4,5-bis(methoxycarbonyl)-1H-1,2,3-triazol-1-yl $\}$ methyl]2-[(4-methylphenyl)sulfonamido]propane-1,3-diyl)bis(1H-1,2,3-triazole-4,5-dicarboxylate) (3) was prepared in two steps starting from 2-((4-methylphenyl)sulfonamido)-2-((tosyloxy)methyl)propane1,3-diylbis(4-methylbenzenesulfonate) (1), with an overall yield of 74\%. The key step being the copperfree Huisgen cycloaddition between $N$-(1,3-diazido-2-(azidomethyl)propan-2-yl)-4-methylbenzenesulfonamide (2) and commercially available dimethyl acetylenedicarboxylate. The chemical structure of compound 3 was determined by IR, 1D and 2D NMR experiments, and elemental analysis.
\end{abstract}

Keywords: azide; nucleophilic substitution reaction; copper-free Huisgen reaction; 2D NMR experiments

\section{Introduction}

Although antibiotics remain an effective means against infectious diseases, microbial resistance is a major scourge on global health [1]. This has led to a rush of researchers towards the synthesis of new heterocyclic compounds, justified mainly by their broad spectrum of application. Thus, in recent decades, the 1,2,3-triazoles have become increasingly targeted, due to their interesting antibacterial [2], antioxidant, antiinflammatory [3], and antifungal properties [4]. They were also used in anti-corrosive treatments [5]. The copper-free Huisgen cycloaddition reaction remains one of the most widely used methods in organic synthesis. It is considered to be the most direct and efficient route to five-membered heterocycles. It is a reaction between a 1,3-dipole and a dipolarophile. The first dipole, the diazoacetic ester, was discovered in 1883 by Curtius [6]. Five years later, Buchner [7] studied the reaction of this dipole with several alkenes, $\alpha, \beta$-unsaturated esters and described the first 1,3-dipolar cycloadditions. Since then, many dipoles have been identified and have found general application in synthesis [8,9], notably through the work of Huisgen [10] whose 1,3-dipolar cycloaddition reaction is also carried out between an azide and a terminal alkyne. This cycloaddition reaction has been widely used in our laboratory [11-20] for the synthesis of new triazole compounds, precursors of heterocyclic amino acids. We cite as examples the diethyl 1-((4methyl-2-phenyl-4,5-dihydrooxazol-4-yl)methyl)-1H-1,2,3-triazole-4,5-dicarboxylate [17], and the N,N-dibenzyl-1-(1-[(4-methyl-2-phenyl-4,5-dihydrooxazol-4-yl)methyl)]-1H-1,2,3triazol-4-yl)methanamine [15]. In the same way, we report in this paper the synthesis of a new tritriazolic compound, namely tetramethyl 1,1'-(2-[\{4,5-bis(methoxycarbonyl)-1H-1,2,3triazol-1-yl\}methyl]-2-[(4-methylphenyl)sulfonamido]propane-1,3-diyl)bis(1H-1,2,3-triazole- 
4,5-dicarboxylate) (3). The latter was obtained in two steps from the compound synthesised in the laboratory, the 2-((4-methylphenyl)sulfonamido)-2-((tosyloxy)methyl)propane-1,3diylbis (4-methylbenzenesulfonate) (1). The approach consisted first to prepare the triazide dipole (2) by nucleophilic substitution of O-tosyl groups of the compound (1) by sodium azide. We then performed a dipolar cycloaddition reaction between the $\mathrm{N}-(1,3-$ diazido-2-(azidomethyl)propan-2-yl)-4-methylbenzenesulfonamide (2), and the dimethyl acetylenedicarboxylate. The cycloadduct (3) obtained with an overall yield of $74 \%$, was fully characterized by 1D and 2D NMR, IR, and elemental analysis (Supplementary Materials).

\section{Results and Discussion}

The starting compound, 2-((4-methylphenyl)sulfonamido)-2-((tosyloxy)methyl)propane1,3-diyl bis(4-methylbenzenesulfonate) (1) was synthesized from the commercial product 2-amino-2-(hydroxymethyl)propane-1,3-diol (CAS No. [77-86-1]) by the action of six equivalents of tosyl chloride in pyridine at $0{ }^{\circ} \mathrm{C}$ for $5 \mathrm{~h}$. The tetratosylated derivative was obtained as pure in $94 \%$ yield after recrystallization in anhydrous methanol.

The three O-tosylated groups are then substituted by the azide function via the action of 3,5 equivalents of sodium azide at reflux in acetonitrile for $24 \mathrm{~h}$, leading to the $\mathrm{N}$-tosyl triazide derivative (2) with a yield of $90 \%$ after recrystallization in ethyl acetate.

The triazide dipole (2) was carried to reflux in the minimum of toluene with 4,5 equivalents of dimethyl acetylenedicarboxylate (CAS No. [762-42-5]), led after stirring for $72 \mathrm{~h}$ to the desired product tetramethyl 1,1'-(2-[\{4,5-bis(methoxycarbonyl)- $1 H-1,2,3$-triazol-1yl\}methyl]-2-[(4-methylphenyl)sulfonamido]propane-1,3-diyl)bis(1H-1,2,3-triazole-4,5dicarboxylate) (3). The $\mathrm{N}$-tosyl tritriazolic derivative (3) was isolated as pure in $82 \%$ yield, as a white solid after chromatography on a silica gel column (methylene chloride/ethyl acetate 9/1) and recrystallization in methylene chloride (Scheme 1).

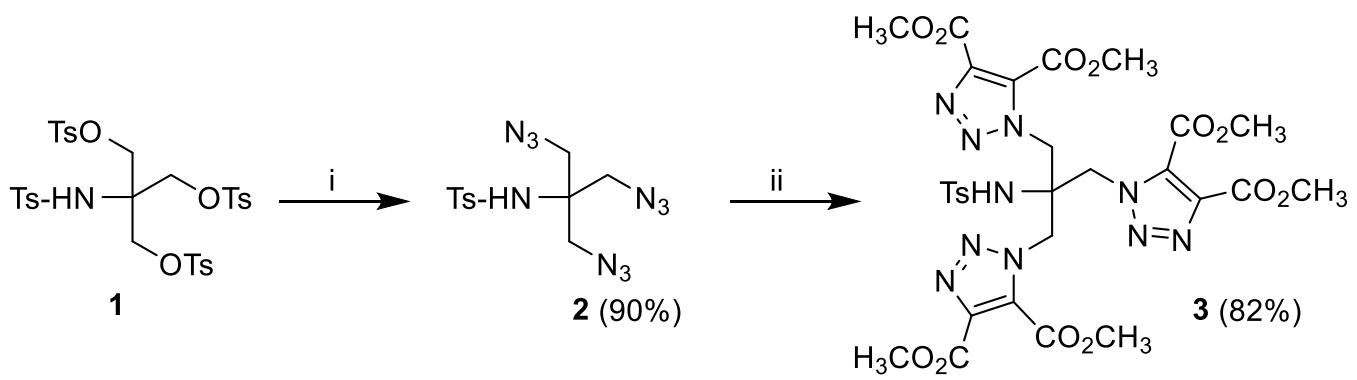

(i) $\mathrm{NaN}_{3}$ (3.5 eq.) $/ \mathrm{CH}_{3} \mathrm{CN}$ - reflux; $24 \mathrm{~h}$

(ii) $\mathrm{H}_{3} \mathrm{CO}_{2} \mathrm{C}=\mathrm{CO}_{2} \mathrm{CH}_{3}$ (4.5 eq.) /Toluene - reflux; $72 \mathrm{~h}$

Scheme 1. Synthetic route for compound (3).

The chemical structure of compound (3) was elucidated by methods of spectroscopic analysis such as 1D and 2D-NMR experiments, infrared spectroscopy, and elemental analysis. The ${ }^{1} \mathrm{H}$ NMR spectrum of the cycloadduct (3) showed the presence of two intense signals at 3.98 and $4.05 \mathrm{ppm}$ corresponding to the 18 methyl protons of the ester groups. Also, the protons of the methylene group of compound (3), which resonate at $5.12 \mathrm{ppm}$, are more deshielded than those of the triazide derivative (2), which resonate at $3.52 \mathrm{ppm}$. All of this can be explained by the change in their chemical environment due to the tensions of the triazole rings. Furthermore, in the ${ }^{13} \mathrm{C}-\mathrm{NMR}$ spectrum of compound (3), the assignment of the signals appearing at about $159.14 \mathrm{ppm}$ and $159.97 \mathrm{ppm}$ to the quaternary carbons of the carbonyl groups, and those appearing at about $132.48 \mathrm{ppm}$ and $139.57 \mathrm{ppm}$ to the quaternary carbons of the 1,2,3-triazole ring, also confirm that the 1,3-dipolar cycloaddition reaction has taken place. In addition, the appearance of signals at approximately $52.89 \mathrm{ppm}$ and $54.25 \mathrm{ppm}$ in the case of the tris-triazole derivative (3) confirms the presence of methoxy groups of the ester function. The definite assignment of the chemical shifts of protons and carbons are shown in Table 1. The interpretation of the homonuclear and heteronuclear 
2D-NMR spectra (Figures 1 and 2) of the cycloadduct (3) showed a perfect correlation, proton-proton and proton-carbon 13.

Table 1. ${ }^{1} \mathrm{H}(300 \mathrm{MHz})$ and ${ }^{13} \mathrm{C}(75 \mathrm{MHz}) \mathrm{NMR}$ spectral data for compound (3) in $\mathrm{CDCl}_{3}$, including results obtained by homonuclear 2D shift-correlated and heteronuclear 2D shift-correlated HMBC. Chemical shifts $(\delta$ in ppm) and coupling constants $(\mathrm{I}$ in $\mathrm{Hz})$.

\begin{tabular}{|c|c|c|c|c|}
\hline Position & $\delta_{H}$ & $\delta_{C}$ & Correlation $\mathrm{H}-\mathrm{H}$ & Correlation C-H \\
\hline 1 & - & 62.1 & - & - \\
\hline $2 ; 2^{\prime} ; 2^{\prime \prime}$ & $5.12(\mathrm{~s})$ & 51.1 & $2 \mathrm{H}^{2}-2 \mathrm{H}^{2} ; 2 \mathrm{H}^{2^{\prime}}-2 \mathrm{H}^{2} ; 2 \mathrm{H}^{2 \prime \prime}-2 \mathrm{H}^{2 \prime \prime}$ & $\mathrm{C}^{2}-2 \mathrm{H}^{2} ; \mathrm{C}^{2}-2 \mathrm{H}^{2^{\prime}} ; \mathrm{C}^{2 \prime \prime}-2 \mathrm{H}^{2^{\prime \prime}}$ \\
\hline $3 ; 3^{\prime} ; 3^{\prime \prime}$ & - & 139.6 & - & - \\
\hline $4 ; 4^{\prime} ; 4^{\prime \prime}$ & - & 132.5 & - & - \\
\hline $5 ; 5^{\prime} ; 5^{\prime \prime}$ & - & 159.1 & - & - \\
\hline $6 ; 6^{\prime} ; 6^{\prime \prime}$ & $4.05(\mathrm{~s})$ & 52.9 & $3 \mathrm{H}^{6}-3 \mathrm{H}^{6} ; 3 \mathrm{H}^{6^{\prime}}-3 \mathrm{H}^{6^{\prime}} ; 3 \mathrm{H}^{6^{\prime \prime}}-3 \mathrm{H}^{6^{\prime \prime}}$ & $\mathrm{C}^{6}-3 \mathrm{H}^{6} ; \mathrm{C}^{6^{\prime}}-3 \mathrm{H}^{6^{\prime}} ; \mathrm{C}^{6^{\prime \prime}}-3 \mathrm{H}^{6^{\prime \prime}}$ \\
\hline $7 ; 7^{\prime} ; 7^{\prime \prime}$ & - & 160.0 & - & - \\
\hline $8 ; 8^{\prime} ; 8^{\prime \prime}$ & $3.97(\mathrm{~s})$ & 54.3 & $3 \mathrm{H}^{8}-3 \mathrm{H}^{8} ; 3 \mathrm{H}^{8^{\prime}}-3 \mathrm{H}^{8^{\prime}} ; 3 \mathrm{H}^{8^{\prime \prime}}-3 \mathrm{H}^{8^{\prime \prime}}$ & $\mathrm{C}^{8}-3 \mathrm{H}^{8} ; \mathrm{C}^{8^{\prime}}-3 \mathrm{H}^{8^{\prime}} ; \mathrm{C}^{8^{\prime \prime}}-3 \mathrm{H}^{8^{\prime \prime}}$ \\
\hline 9 & $6.64(\mathrm{~s})$ & - & - & - \\
\hline 10 & - & 144.3 & - & - \\
\hline $11 ; 11^{\prime}$ & $7.16(\mathrm{~d}, J=8.25)$ & 126.1 & $1 \mathrm{H}^{11}-1 \mathrm{H}^{11} ; 1 \mathrm{H}^{11^{\prime}}-1 \mathrm{H}^{11^{\prime}}$ & $\mathrm{C}^{11}-1 \mathrm{H}^{11} ; \mathrm{C}^{11^{\prime}}-1 \mathrm{H}^{11^{\prime}}$ \\
\hline $12 ; 12^{\prime}$ & $7.38(\mathrm{~d}, J=8.34)$ & 130.0 & $1 \mathrm{H}^{12}-1 \mathrm{H}^{12} ; 1 \mathrm{H}^{12^{\prime}}-1 \mathrm{H}^{12^{\prime}}$ & $\mathrm{C}^{12}-1 \mathrm{H}^{12} ; \mathrm{C}^{12^{\prime}}-1 \mathrm{H}^{12^{\prime}}$ \\
\hline 13 & - & 138.4 & - & - \\
\hline 14 & $2.37(\mathrm{~s})$ & 21.5 & $3 \mathrm{H}^{14}-3 \mathrm{H}^{14}$ & $\mathrm{C}^{14}-3 \mathrm{H}^{14}$ \\
\hline
\end{tabular}

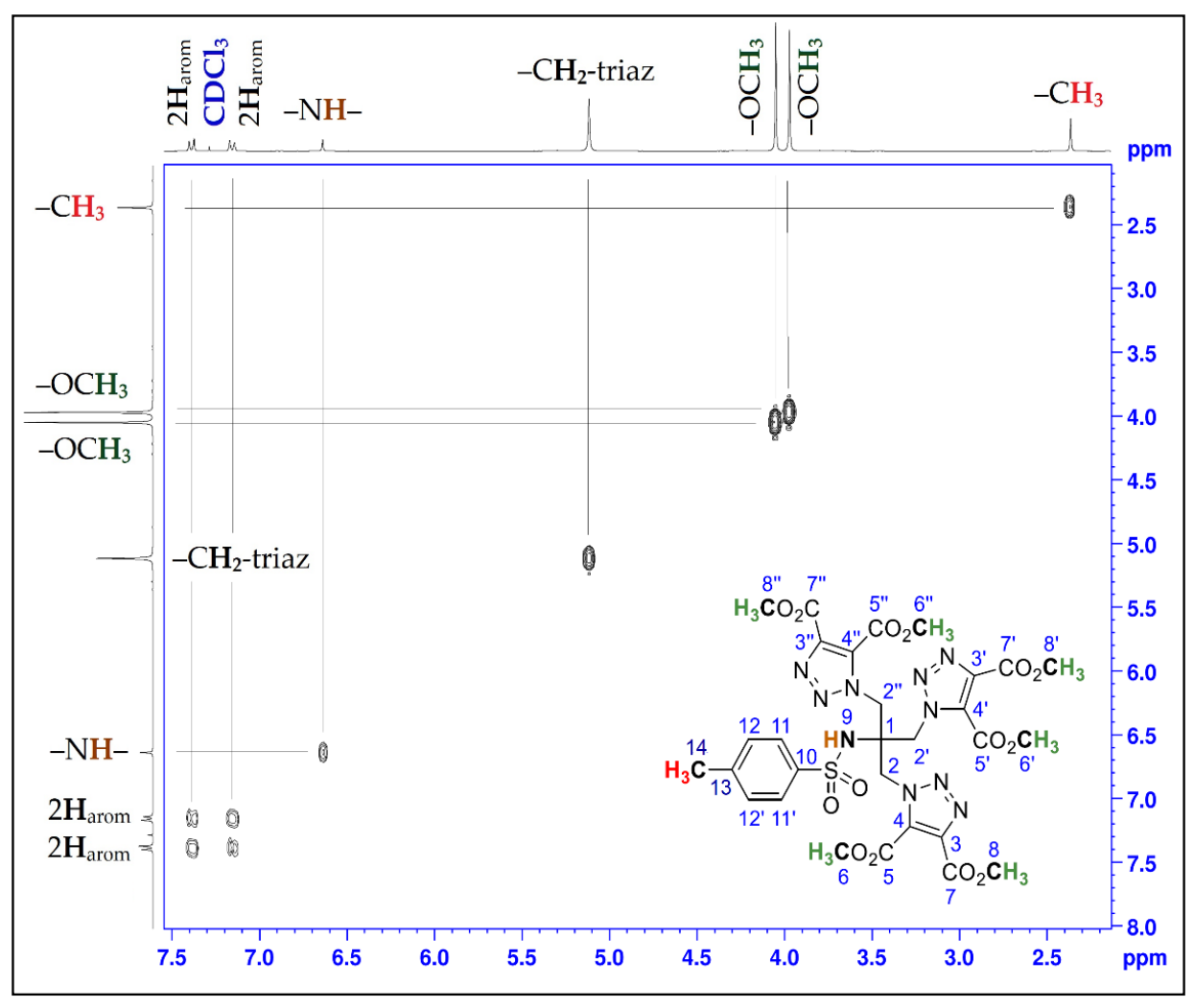

Figure 1. 2D COSY spectrum of compound (3). 


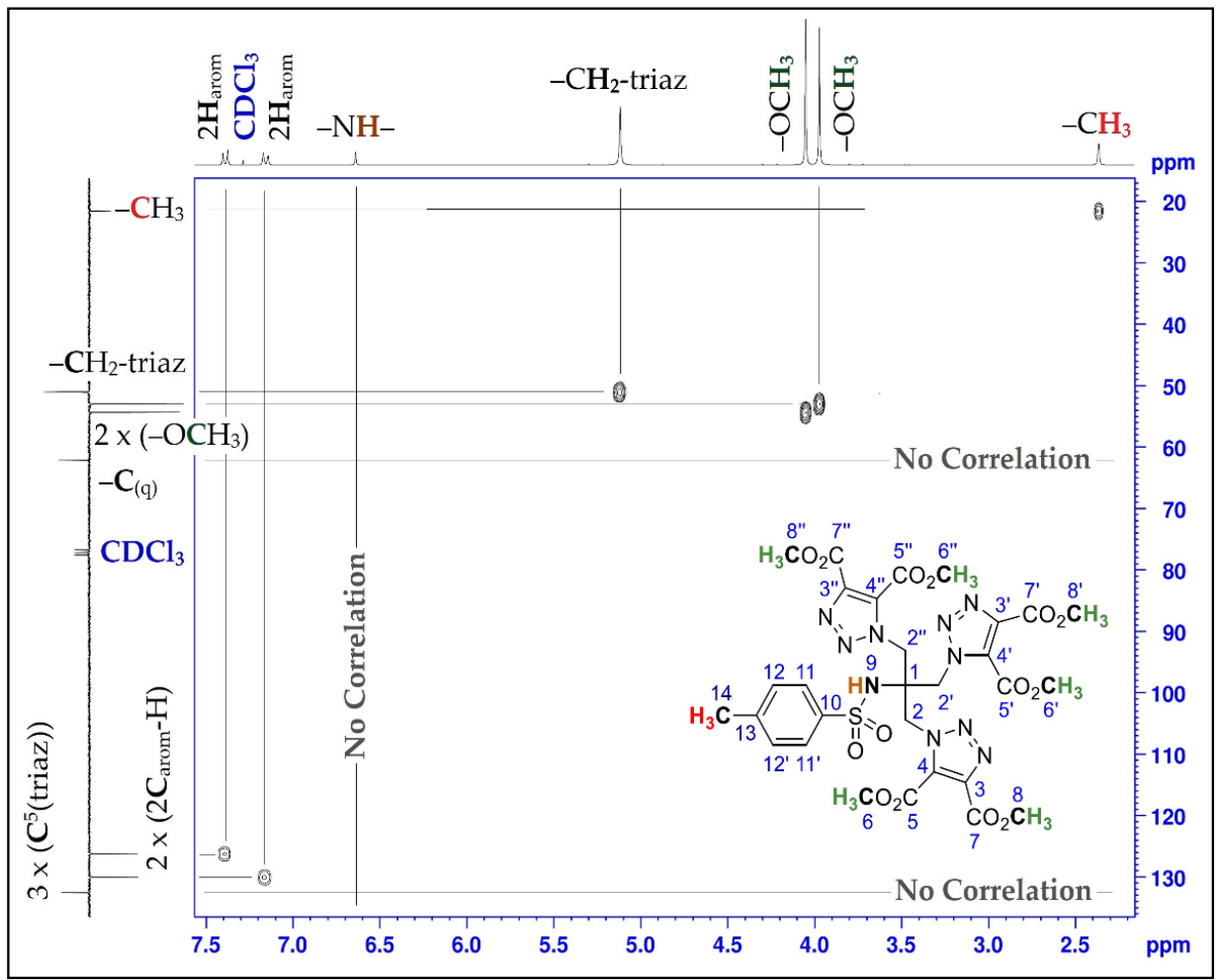

Figure 2. 2D HSQC spectrum of compound (3).

The IR spectrum of compound (2), shows inter alia, a high-intensity band at $2100 \mathrm{~cm}^{-1}$, characteristic for stretching vibrations of the azide group $\left(-\mathrm{N}_{3}\right)$. Thus, in the spectrum of compound (3), we marked the absence of this last band and the presence of another at $3600 \mathrm{~cm}^{-1}$, characteristic of triazole ring, and two high-intensity bands at $1700-1750 \mathrm{~cm}^{-1}$, characteristics for vibrations of the carbonyl groups $(\mathrm{C}=\mathrm{O})$ of ester fragments. We also note the presence of the two other bands at $1350 \mathrm{~cm}^{-1}$ characteristics for stretching vibrations of the (C-O) bonds of ester functions. All of this clearly confirms that the cycloaddition reaction has been carried out.

\section{Materials and Methods}

All solvents were purified following the standard techniques and commercial reagents were purchased from Sigma-Aldrich (St. Louis, MO, USA). Melting point was determined with an electrothermal melting point apparatus and was uncorrected. NMR spectra $\left({ }^{1} \mathrm{H}\right.$ and $\left.{ }^{13} \mathrm{C}\right)$ were recorded on a Bruker AM 300 spectrometer (operating at $300 \mathrm{MHz}$ for ${ }^{1} \mathrm{H}$, at $75 \mathrm{MHz}$ for ${ }^{13} \mathrm{C}$ ) (Bruker Analytische Messtechnik \& $\mathrm{GmbH}$, Rheinstetten, Germany). NMR data are listed in ppm and are reported relative to tetramethylsilane $\left({ }^{1} \mathrm{H},{ }^{13} \mathrm{C}\right)$; residual solvent peaks being used as an internal standard. NMR spectroscopic data were recorded in $\mathrm{CDCl}_{3}$ using as internal standards the residual non-deuterated signal $(\delta=7.26 \mathrm{ppm})$ for ${ }^{1} \mathrm{H}$ NMR and the deuterated solvent signal $(\delta=77.16 \mathrm{ppm})$ for ${ }^{13} \mathrm{C}$ NMR spectroscopy. DEPT spectra were used for the assignment of carbon signals. Chemical shifts $(\delta)$ are given in ppm and coupling constants $(J)$ are given in Hz. The following abbreviations are used for multiplicities: $\mathrm{s}=$ singlet, and $\mathrm{d}=$ doublet. All reactions were followed by TLC. TLC analyses were carried out on $0.25 \mathrm{~mm}$ thick precoated silica gel plates (Merck Fertigplatten Kieselgel $60 \mathrm{~F}_{254}$ ) and spots were visualized under UV light or by exposure to vaporized iodine. The FT-IR spectrum was recorded in $\mathrm{KBr}$ pellet on a Bruker Vertex 70 FTIR spectrometer. Elemental analysis was performed with a Flash 2000 EA 1112, Thermo Fisher Scientific-Elemental Analyzer (CNRST-Rabat, Rabat, Morocco). 


\subsection{Synthesis of N-(1,3-Diazido-2-(azidomethyl)propan-2-yl)-4-methylbenzenesulfonamide (2)}

To $10 \mathrm{~mL}$ acetonitrile, $1.3 \mathrm{mmol}(958.1 \mathrm{mg})$ of product (1) and $4.55 \mathrm{mmol}(295.7 \mathrm{mg})$ (3,5 eq.) of sodium azide (CAS No. [26628-22-8]) were added and the mixture is refluxed under stirring for $24 \mathrm{~h}$ at $80^{\circ} \mathrm{C}$. At the end of the reaction, the mixture was filtered and then concentrated under vacuum. The residue was washed with water then dried in a vacuum desiccator under $\mathrm{P}_{2} \mathrm{O}_{5}$. The obtained product was recrystallized in ethyl acetate.

Yield $=90 \%$ (white solid); m.p. $=68-70{ }^{\circ} \mathrm{C}, \mathrm{Rf}=0.48$ (ether $/$ hexane: $2 / 3$ ). ${ }^{1} \mathrm{H}-\mathrm{NMR}$ $\left(\mathrm{CDCl}_{3}, \delta_{\mathrm{H}} \mathrm{ppm}, 300 \mathrm{MHz}\right): 2.46\left(\mathrm{~s}, 3 \mathrm{H},-\mathrm{CH}_{3}\right) ; 3.52\left(\mathrm{~s}, 6 \mathrm{H}, 3 \times\left(-\mathrm{CH}_{2}-\mathrm{N}_{3}\right)\right) ; 5.59(\mathrm{~s}, 1 \mathrm{H},-\mathrm{NH}-$ ); $7.37\left(\mathrm{~d},{ }^{3} \mathrm{~J}=7.8 \mathrm{~Hz}, 2 \mathrm{H}_{\text {arom }}\right) ; 7.87\left(\mathrm{~d},{ }^{3} \mathrm{~J}=8.4 \mathrm{~Hz}, 2 \mathrm{H}_{\text {arom }}\right) .{ }^{13} \mathrm{C} \mathrm{RMN} \delta_{\mathrm{C}}\left(\mathrm{ppm}, \mathrm{CDCl}_{3}, 75\right.$ $\mathrm{MHz})$ : $21.6\left(1 \mathrm{C},-\mathrm{CH}_{3}\right) ; 52.3\left(3 \mathrm{C}, 3 \times\left(-\mathrm{CH}_{2}-\mathrm{N}_{3}\right)\right) ; 61.3\left(1 \mathrm{C},-\mathrm{C}_{\mathrm{q}}(\mathrm{NH})\right) ; 126.7\left(2 \mathrm{C}, 2 \times\left(\mathrm{C}_{\mathrm{arom}^{-}}{ }^{-}\right.\right.$ $\mathrm{H})) ; 129.9\left(2 \mathrm{C}, 2 \times\left(\mathrm{C}_{\text {arom }}-\mathrm{H}\right)\right) ; 138.5\left(1 \mathrm{C}, \mathrm{C}_{\text {arom }}-\mathrm{CH}_{3}\right) ; 144.2\left(1 \mathrm{C}, \mathrm{C}_{\text {arom }}-\mathrm{SO}_{2}\right)$. IR $\left(v\left(\mathrm{~cm}^{-1}\right)\right)$ : $3250(=\mathrm{CH}) ; 2940(\mathrm{~N}-\mathrm{H}) ; 2100\left(-\mathrm{N}_{3}\right) ; 1580(\mathrm{~N}-\mathrm{H}$ (bending)); $1350(\mathrm{~S}=\mathrm{O}$ (stretching)); 780 $(=\mathrm{CH})$.

3.2. Synthesis of Tetramethyl 1,1'-(2-[\{4,5-bis(Methoxycarbonyl)-1H-1,2,3-triazol-1-yl]methyl]-2[(4-methylphenyl)sulfonamido]propane-1,3-diyl)bis(1H-1,2,3-triazole-4,5-dicarboxylate) (3)

In the minimum of toluene $(\sim 5 \mathrm{~mL}), 2 \mathrm{mmol}(700.0 \mathrm{mg})$ of triazide derivative (2) and $9 \mathrm{mmol}(1278.0 \mathrm{mg}$ ) of dimethyl acetylenedicarboxylate (CAS No. [762-42-5]) were dissolved. The mixture was heated under reflux with stirring for three days. At the end of the reaction, the solvent was removed under reduced pressure and the crude reaction was purified by chromatography on a silica gel column (eluent: methylene chloride/ethyl acetate 9/1). The product thus isolated was recrystallized in methylene chloride.

Yield $=82 \%$ (white solid); m.p. $=176-177^{\circ} \mathrm{C}, \mathrm{Rf}=0.47$ (ethyl acetate $/$ methylene chloride 7/3). ${ }^{1} \mathrm{H}-\mathrm{NMR}\left(\mathrm{CDCl}_{3}, \delta_{\mathrm{H}} \mathrm{ppm}, 300 \mathrm{MHz}\right): 2.37\left(\mathrm{~s}, 3 \mathrm{H},-\mathrm{CH}_{3}\right) ; 3.97(\mathrm{~s}, 9 \mathrm{H}$, $\left.3 \times\left(-\mathrm{OCH}_{3}\right)\right) ; 4.05\left(\mathrm{~s}, 9 \mathrm{H}, 3 \times\left(-\mathrm{OCH}_{3}\right)\right) ; 5.12\left(\mathrm{~s}, 6 \mathrm{H}, 3 \times\left(-\mathrm{CH}_{2}\right.\right.$-triaz) $) ; 6.64(\mathrm{~s}, 1 \mathrm{H},-\mathrm{NH}-)$; $7.16\left(\mathrm{~d},{ }^{3} \mathrm{~J}=8.25 \mathrm{~Hz}, 2 \mathrm{H}_{\text {arom }}\right) ; 7.38\left(\mathrm{~d},{ }^{3} \mathrm{~J}=8.34 \mathrm{~Hz}, 2 \mathrm{H}_{\text {arom }}\right) .{ }^{13} \mathrm{C}-\mathrm{NMR}\left(\mathrm{CDCl}_{3}, \delta_{\mathrm{C}} \mathrm{ppm}\right.$, $75 \mathrm{MHz}): 21.5\left(1 \mathrm{C},-\mathrm{CH}_{3}\right) ; 50.9\left(3 \mathrm{C}, 3 \times\left(-\mathrm{CH}_{2}\right.\right.$-triaz $\left.)\right) ; 52.9\left(3 \mathrm{C}, 3 \times\left(-\mathrm{OCH}_{3}\right)\right) ; 54.3(3 \mathrm{C}$, $\left.3 \times\left(-\mathrm{OCH}_{3}\right)\right) ; 62.1\left(1 \mathrm{C},-\mathrm{C}_{\mathrm{q}}(\mathrm{NH})\right) ; 126.1\left(2 \mathrm{C}, 2 \times\left(\mathrm{C}_{\text {arom }}-\mathrm{H}\right)\right) ; 130.0\left(2 \mathrm{C}, 2 \times\left(\mathrm{C}_{\text {arom }}-\mathrm{H}\right)\right)$; $132.5\left(3 \mathrm{C}, 3 \times\left(\mathbf{C}^{5}\right.\right.$ (triaz)); $138.4\left(1 \mathrm{C}, \mathbf{C}_{\text {arom }}-\mathrm{CH}_{3}\right) ; 139.6\left(3 \mathrm{C}, 3 \times\left(\mathbf{C}^{4}\right.\right.$ (triaz)); $144.3\left(1 \mathrm{C}, \mathbf{C}_{\text {arom }}{ }^{-}\right.$ $\left.\mathrm{SO}_{2}\right) ; 159.1(3 \mathrm{C}, 3 \times \mathrm{CO}) ; 160.0(3 \mathrm{C}, 3 \times \mathrm{CO})$. IR $\left(v\left(\mathrm{~cm}^{-1}\right)\right)$ : 3600 (triazole ring); $3250(=\mathrm{CH})$; 2900 (N-H); 1700-1750 (C=O two bands); 1580 (N-H(bending)); 1350 (C-O two bands); 1300 $\left(\mathrm{S}=\mathrm{O}\right.$ (stretching)); $820(=\mathrm{CH})$. Anal. Calcd. for $\mathrm{C}_{29} \mathrm{H}_{32} \mathrm{~N}_{10} \mathrm{O}_{14} \mathrm{~S}(\%): \mathrm{C}, 44.85 ; \mathrm{H}, 4.15 ; \mathrm{N}$, 18.03; Found (\%): C, 44.74; H, 4.18; N, 18.07.

\section{Conclusions}

The synthesis of the title compound, tetramethyl 1,1'-(2-[\{4,5-bis(methoxycarbonyl)-1H1,2,3-triazol-1-yl\}methyl]-2-[(4-methylphenyl)sulfonamido]propane-1,3-diyl)bis(1H-1,2,3triazole-4,5-dicarboxylate) (3), was carried out with a good yield, via 1,3-dipolar cycloaddition reaction between $\mathrm{N}$-(1,3-diazido-2-(azidomethyl)propan-2-yl)-4-methylbenzenesulfonamide and dimethyl but-2-ynedioate. The characterization of its structure was performed by $1 \mathrm{D}$ and 2D NMR spectroscopy, IR, and elemental analysis. The evaluation of the anti-corrosion and biological activities of the synthesized product is under way.

Supplementary Materials: The following data are available online: Figure S1: ${ }^{1} \mathrm{H}-\mathrm{NMR}$ spectrum of compound (1), Figure S2: ${ }^{13} \mathrm{C}-\mathrm{NMR}$ spectrum of compound (1), Figure S3: 2D COSY spectrum of compound (1), Figure S4: 2D COSY spectrum (aromatic part) of compound (1), Figure S5: 2D HSQC spectrum of compound (1), Figure S6: 2D HSQC spectrum (aromatic part) of compound (1) Figure S7: IR spectrum of compound (3): Figure S8: ${ }^{1} \mathrm{H}-\mathrm{NMR}$ spectrum of compound (2), Figure S9: ${ }^{13} \mathrm{C}-\mathrm{NMR}$ spectrum of compound (2); Figure S10: 2D COSY spectrum of compound (2), Figure S11: 2D HSQC spectrum of compound (2); Figure S12: IR spectrum of compound (2); Figure S13: ${ }^{1} \mathrm{H}-\mathrm{NMR}$ spectrum of compound (3), Figure S14: ${ }^{13}$ C-NMR spectrum of compound (3), Figure S15: 2D COSY spectrum of compound (3), Figure S16: 2D HSQC spectrum of compound (3), Figure S17: IR spectrum of compound (3). 
Author Contributions: S.A.K.F. and S.H. performed the experiments; H.F. and A.A. conceived and designed the experiments; O.K., S.B., Y.A. and A.A. analyzed the data; Y.A. and A.A. wrote the paper. All authors have read and agreed to the published version of the manuscript.

Funding: This research received no external funding.

Institutional Review Board Statement: Not applicable.

Informed Consent Statement: Not applicable.

Data Availability Statement: The data presented in this study are available in the Supplementary Materials.

Acknowledgments: This work was supported by Sidi Mohammed Ben Abdellah University (USMBA) and National Center for Scientific and Technical Research (CNRST).

Conflicts of Interest: The authors declare no conflict of interest.

\section{References}

1. Zarei, S.; Komeili, G.; Bahadorikhalili, S.; Yahya-Meymandi, A.; Karami-Zarandi, M.; Larijani, B.; Biglar, M.; Sadat Ebrahimi, S.E.; Mahdavi, M. Design, synthesis and antibacterial activity evaluation of novel 2-(4-((1-aryl-1H-1,2,3-triazol-4-yl)methoxy)phenyl)2(2-oxoazetidin-1-yl)acetamide derivatives. J. Heterocycl. Chem. 2020, 57, 4254-4261. [CrossRef]

2. Singh, G.; Singh, J.; Singh, A.; Singh, J.; Kumar, M.; Gupta, K.; Chhibber, S. Synthesis, characterization and antibacterial studies of schiff based 1,2,3-triazole bridged silatranes. J. Organomet. Chem. 2018, 871, 21-27. [CrossRef]

3. Rani, A.; Singh, G.; Singh, A.; Maqbool, U.; Kaur, G.; Singh, J. CuAAC-ensembled 1,2,3-triazole-linked isosteres as pharmacophores in drug discovery: Review. RSC Adv. 2020, 10, 5610-5635. [CrossRef]

4. Kaushik, C.P.; Luxmi, R.; Kumar, M.; Singh, D.; Kumar, K.; Pahwa, A. One-pot facile synthesis, crystal structure and antifungal activity of 1,2,3-triazoles bridged with amine-amide functionalities. Synth. Commun. 2019, 49, 118-128. [CrossRef]

5. González-Olvera, R.; Espinoza-Vázquez, A.; Negrón-Silva, G.E.; Palomar-Pardavé, M.E.; Romero-Romo, M.A.; Santillan, R. Multicomponent click synthesis of new 1,2,3-triazole derivatives of pyrimidine nucleobases: Promising acidic corrosion inhibitors for steel. Molecules 2013, 18, 15064-15079. [CrossRef] [PubMed]

6. Curtius, T. Ueber die Einwirkung von salpetriger Säure auf salzsauren Glycocolläther. Ber. der Dtsch. Chem. Ges. 1883, 16, 2230-2231. [CrossRef]

7. Buchner, E. Einwirkung von diazoessigäther auf die aether ungesättigter säuren. Ber. der Dtsch. Chem. Ges. 1888, 21, 2637-2647. [CrossRef]

8. 1,3-Dipolar cycloaddition chemistry. Volumes 1 and 2. Edited by Albert Padwa. John Wiley and Sons. New York, 1984. Volume 1: XIII + 817 pages. Volume 2: XIII + 704 pages. J. Heterocycl. Chem. 1986, 23, 1899. [CrossRef]

9. Suga, H. Synthetic Applications of 1,3-Dipolar Cycloaddition Chemistry. Towards Heterocycles and Natural Products (Series: Chem-istry of Heterocyclic Compounds, Vol. 59). Angew. Chem. Int. Ed. 2003, 42, 4569-4570. [CrossRef]

10. Huisgen, R. 1,3-Dipolar cycloadditions. Past and Future. Angew. Chem. Int. Ed. Engl. 1963, 2, 565-598. [CrossRef]

11. Atmani, A.; El Hallaoui, A.; El Hajji, S.; Roumestant, M.L.; Viallefont, P. From oxazolines to precursors of amino acids. Synth. Commun. 1991, 21, 2383-2390. [CrossRef]

12. Labriti, B.; El Hallaoui, A.; Elachqar, A.; Alami, A.; El Hajji, S.; Boukallaba, K.; El Bali, B.; Lachkar, M.; Allouchi, H.; Martinez, J.; et al. Synthesis of 2-phenyl-4-methyl-4-((tetrazol-5-yl)methyl) oxazoline. Mor. J. Heterocycl. Chem. 2006, 5, 58-61. [CrossRef]

13. Aouine, Y.; Faraj, H.; Alami, A.; El Hallaoui, A.; Elachqar, A.; El Hajji, S.; Kerbal, A.; Labriti, B.; Martinez, J.; Rolland, V. Synthesis of new triheterocyclic compounds, precursors of biheterocyclic aminoacids. Mor. J. Heterocycl. Chem. 2008, 7, 44-49. [CrossRef]

14. Aouine, Y.; Faraj, H.; Alami, A.; El Hallaoui, A.; El Hajji, S.; Labriti, B.; Kerbal, A. Triheterocyclic compounds, oxazolinic precursors of biheterocyclic amino acids, Part II: Phenothiazine derivatives and structural study of regioisomers through ${ }^{1} \mathrm{H}-{ }^{15} \mathrm{~N} 2 \mathrm{D}$ NMR HMBC. Mor. J. Heterocycl. Chem. 2014, 13, 39-47. [CrossRef]

15. Younas, A.; Abdelilah, E.H.; Anouar, A. N,N-Dibenzyl-1-(1-[(4-methyl-2-phenyl-4,5-dihydrooxazol-4-yl)methyl)]-1H-1,2,3-triazol4-yl)methanamine. Molbank 2014, 2014, M819. [CrossRef]

16. Achamlale, S.; Alami, A.; Aouine, Y. Structure assignment of $\mathrm{N}$-protected 2-(1H-1,2,3- triazol-1-yl)-glycine derivatives by chemical and spectroscopic methods. Mor. J. Heterocycl. Chem. 2019, 18, 61-69. [CrossRef]

17. Boukhssas, S.; Aouine, Y.; Faraj, H.; Alami, A.; El Hallaoui, A.; Bekkari, H. Synthesis, characterization, and antibacterial activity of diethyl 1-((4-methyl-2-phenyl-4,5-dihydrooxazol-4-yl)methyl)-1H-1,2,3-triazole-4,5-dicarboxylate. J. Chem. 2017, 2017, 4238360. [CrossRef]

18. Achamlale, S.; Elachgar, A.; El Hallaoui, A.; Alami, A.; El Hajji, S.; Roumestant, M.L.; Viallefont, P. Synthesis of biheterocyclic $\alpha$-amino acids. Amino Acids 1999, 17, 149-163. [CrossRef] [PubMed] 
19. Dioukhane, K.; Moussaid, S.; Achamlale, S.; Alami, A.; Kabbour, M.R.; Aouine, Y.; Faraj, H.; Bouksaim, M.; Gaye, M.L. Comparative study of antibacterial activity of some biheterocyclic "triazolic-tetrazolic" $\alpha$-amino acid derivatives against bacterial strains. Mor. J. Heterocycl. Chem. 2020, 19, 87-91. [CrossRef]

20. Hajib, S.; Ksakas, A.; Aouine, Y.; Alami, A.; Faraj, H. Synthesis and structural determination of two new tri-heterocyclic regioisomeric compounds, precursors of bi-triazolic $\alpha$-amino acids, via a comparative study using 1D NMR Spectroscopy. Eur. J. Adv. Chem. Res. 2020, 1, 1-6. [CrossRef] 